\title{
RESISTENSI KEPEMIMPINAN PEREMPUAN EKS-HIZBUT TAHRIR DALAM LEMBAGA PENDIDIKAN DASAR ISLAM DI KOTA KEDIRI
}

\author{
Ahmad Khoirul Mustamir \\ Institut Agama Islam Tribakti Kediri \\ khoirulkdr52@gmail.com \\ Muslimin \\ Institut Agama Islam Tribakti Kediri \\ musliminiait@gmail.com
}

\begin{abstract}
The phenomenon of the entry of radicalism in Islamic basic educational institutions through various forms of media and methods. As a result, not a few basic Islamic educational institutions are exposed to radicalism. Hence, the role of the principal against radicalism is significant. In Kediri, many basic Islamic educational institutions are led by female leaders who are perceived as second class. This research used a qualitative method with a feminism perspective. The object of study is SDI AL Huda Kediri City (NU), Wahidiyah SDI Kediri City and SD Plus Ar Rahmat Kediri City (Muhamadiyah). The results showed that all school principals used formal and non-formal approaches in fighting against radicalism (ex-HTI). The formal approach used learning programs and extracurricular activities. While the non-formal approach utilized the meeting of the parents. This proved, the role of women is very significant in fighting the understanding of ex-HTI in basic Islamic education institutions in the City of Kediri.
\end{abstract}

Keywords: Resistance, Female Leader, ex-HTI.

\begin{abstract}
Abstrak
Fenomena masuknya radikalisme di lembaga pendidikan dasar Islam melalui berbagai bentuk media dan cara. Alhasil, tidak sedikit lembaga pendidikan dasar Islam yang terkena virus radikalisme. Karenanya, peran prinsipal melawan radikalisme menjadi sangat penting. Di Kediri, banyak lembaga pendidikan dasar Islam dipimpin oleh pemimpin perempuan yang dianggap sebagai kelas dua. Penelitian ini menggunakan metode kualitatif dengan perspektif feminisme. Objek penelitian adalah SDI AL Huda Kota Kediri (NU), SDI Wahidiyah Kota Kediri dan SD Plus Ar Rahmat Kota Kediri (Muhamadiyah). Hasil penelitian menunjukkan bahwa semua kepala sekolah menggunakan pendekatan formal dan nonformal dalam memerangi radikalisme (eks-HTI). Pendekatan formal menggunakan program pembelajaran dan kegiatan ekstrakurikuler. Sedangkan pendekatan nonformal memanfaatkan pertemuan orang tua. Ini membuktikan, peran perempuan sangat signifikan dalam memperjuangkan pemahaman eks-HTI di lembaga pendidikan dasar Islam di Kota Kediri.

Kata kunci: Resistensi, Kepemimpinan Perempuan, Mantan HTI
\end{abstract}

\section{PENDAHULUAN}

Fenomena penyebaran paham eks-Hizbut Tahrir Indonesia (HTI) yang mengatasnamakan agama di Indonesia menjadi perhatian serius dari berbagai elemen. Perhatian ini sebagai reaksi atas kekhawatiran kemunculan kembali Islam radikal di Indoensia. Meskipun semua pun sudah menyakini bahwa gerakan Islam radikal tidak pernah mati. Hipotesanya, jika paham radikal menguat maka kerukunan umat beragama di Indonesia akan terganggu. Kehidupan berbangsa dan bernegara akan diwarnai dengan konflik-konflik (Bruinessen, 1994:127). 
Di Jawa Timur, gerakan radikalisme juga tidak bisa dipandang sebelah mata. Indikator untuk melihatnya adalah tingginya peristiwa-peristiwa konflik berlatar belakang agama. Catatan Wahid Institute tahun 2015, Jawa Timur menempati peringkat kelima konflik berlatarbelakang agama di Indonesia (Wahid Institut, 2015). Fakta mengejutkan, Catatan Setara Institute tahun 2017 menempatkan Jawa Timur di posisi keempat dengan kasus bernuansa agama (Institute, n.d. 2017)

Selain catatan-catatan lembaga pemantau nasional tersebut, paham radikalisme menjangkiti anak-anak. Fakta ini tercermin pada peristiwa pengeboman di Gereja Santa Maria Tak Bercela, GKI Diponegoro, Gereja Pantekosta Pusat Surabaya (GPPS) Jemaat Sawahan, Rusunawa Wonocolo Sidoarjo, dan Markas Polrestabes Surabaya di tahun 2018. Pelaku pengeboman melibatkan anak-anak dalam aksinya. Dengan peristiwa tersebut, banyak peneliti mencari akar permasalahan faktor atau fasilitas apa yang menjadikan anak-anak juga terlibat dalam gerakan radikalisme. Salah satu faktor yang ikut menjadikan subur pemahaman dan aksi radikalisme agama di Indonesia adalah pendidikan (Hamdi, 2013). Melalui pendidikan inilah yang membentuk karakter dan mampu mendorong seseorang melakukan segala tindakan. Sehingga lembaga pendidikan apa pun jenisnya memiliki tugas yang besar untuk menghadapi masalah ini. Terlebih lembaga pendidikan keagamaan (Kisbiyanto \& Setyoningsih, 2018).

Tidak bisa dipungkiri, saat ini, gerakan radikalisme masuk dalam dunia pendidikan. Beberapa studi telah memperlihatkan fakta tersebut. Paham radikal masuk dalam dunia pendidikan melalui berbagai macam cara misalnya, melalui kegiatan ektrakurikuler keagamaan Rohis, jaringan alumni yang berafiliasi dengan gerakan radikal, dan bahkan masuk dalam buku pembelajaran pendidikan agama Islam (PAI) melalui konten-konten. Parahnya, berbagai temuan fakta menunjukkan guru-guru agama pun cenderung senada dengan paham-paham radikalisme, meskipun tidak melakukan tindakan, hanya persetujuan (Yani \& Jazariyah, 2020).

Studi PPMI UIN Tahun 2016 menunjukkan, 81\% guru PAI tidak setuju memberikan izin pendirian rumah ibadah bagi penganut agama lain di lingkungan tempat tinggalnya, sebanyak 74\% mereka menolak memebrikan ucapan selamat hari raya kepada pemeluk agama lain dan $80 \%$ tidak bersedia merima atau menampung jamaah Syi'ah ataupun Ahmadiyah yang diusir dari kampung halaman. Hasil survey ini menegaskan bahwa sikap dan persetujuan paham radikalisme bisa dilihat dari sikap dan perilaku terhadap kelompok minoritas agama yang berbeda. Indikatorindikalor ini menunjukkan adanya level atau tahapa-tahapan dalam memotret pemahaman radikalisme (Fathurrohman \& Nurhadi, 2016).

Sementara itu, dalam konteks penyebaran paham radikalisme pada peserta didik usia dini juga sangat memprihatinkan. Data yang dikeluarkan oleh Tempo menyebutkan, banyak beberapa kasus yang menyebutkan, anak-anak mempromosikan ideologi HTI dibarengi dengan penolakan ideologi Pancasila. 
Parahnya, ada sekolah yang melarang peserta didik untuk hormat bendera saat upacara, seperti di Pare-Pare, Palu. Di Jawa Timur pun terjadi, misalnya di Kota Probolinggo pada 2018. Murid-murid TK Kartika V yang berada di bawah naungan Kodim 0820 Probolinggo, menggunakan atribut ISIS dalam acara pawai (Lutvi, n.d.2015).

Sejatinya, fenomena ini bisa dilihat sebagai buah keberhasilan strategi infiltrasi paham HTI pada lembaga pendidikan. Seperti hasil penelitian Erni Sari Dwi Defi Lubis yang menemukan, infiltrasi pada buku ajar Pendidikan Agama Islam tingkat Sekolah Dasar (SD) di Jogjakarta (Lubis, 2018). Temuan sama dapat dilihat dalam penelitian Khosim yang menjelaskan secara eksplisit tentang pengenalan ideologi HTI dengan menegasikan tentang kesalahan ideologi Pancasila. Di Tulungagung dan Kediri pun juga pernah terjadi. Pada Tahun 2019, soal-soal ujian Pendidikan Agama Islam (PAI) ditemukan tentang bentuk negara yang baik adalah khilafah. Menariknya, semua steakholder seolah cuci tangan, bahwa fenomen tersebut bentuk kecolongan dari Kementrian Agama tingkat Kabupaten (Ma'arifah, 2019).

Di Kediri, menarik untuk didalami dalam bentuk penelitian. penelitian, tidak hanya berdasarkan pola penyebaran yang bisa dibenturkan dengan usaha kelompok-kelompok Islam moderat melawan radikalisme, seperti Ansor Kota Kediri, akan tetapi juga karena ada usaha kepala sekolah untuk melakukan perlawanan terhadap penyebaran ideologi HTI. Seperti yang disampaikan Ibu Munawaroh, Kepala Sekolah Sekolah Dasar Islam (SDI) Al Huda Kota Kediri bahwa, kita sejak awal sudah tahu tentang bahaya penyebaran paham radikalisme, untuk itu kami dalam menerima guru selalu menggunakan kreteria pemahaman tentang ahlussunah wal jamaah annahdliyah (Wawancara Munawaroh). Pandangan yang sama juga dikemukaan oleh Ibu Nuning, Kepala Sekolah SDI Terpadu Al Azhar Kota Kediri. Menurutnya, kami selalu memeriksa isi bahan ajar dari setiap mata pelajaran Agama Islam. Dan setiap ada temuan, langsung kita sampaikan untuk ditolak.

Berdasarkan konteks kajian di atas, kepela sekolah perempuan di lembaga pendidikan Islam dasar mempunyai peran dalam melakukan gerakan resistensi terhadap ideologi radikalisme. Fenomena perempuan melawan gerakan ideologi radikalisme bukan hal yang baru. Seperti penelitian Ach Khatib, tentang Perempuan Pamekasan Madura dan Organisasi Islam Radikal (Kajian Reseleansi dan Resistensi Perempuan Atas Aliran HTI di Madura) yang mentarakan, kaum perempuan di Pamekasan juga memiliki kemampuan melakukan resiliensi atas HTI yang mulai inflitrasi, tumbuh, dan berkembang di lingkungannya. Perempuan Pamekasan yang memiliki kelembutan, bersikap tunduh-patuh, tampak kurang memiliki perhatian akan isu-isu keagamaan kontemporer, ternyata menyimpan kemampuan melakukan resiliensi atas HTI. Sedikitnya terdapat dua alasan menempatkan resiliensi 
perempuan Pamekasan sebagai sesuatu yang menarik: pertama, kalau memperhatikan demografi Madura (Khatib, 2018).

Sementara itu, banyak perempuan muslim melakukan pola resistensi terhadap gerakan radikalisme tersebut. Akan tetapi tidak banyak yang menstudi. Menurut hemat peneliti, hal ini dikarenakan perspektif patriarki yang bersemanyam dalam kepala peneliti. Perempuan tidak dianggap mampu untuk melakukan gerakan resistensi. Maka dari itu, penelitian ini sangat penting untuk dilakukan. Perempuan mempunyai suara dan pengalaman, eksistensi di ruang sosial. Berdasarkan kajian di atas penulis melalui penelitian ini mencari jawaban tentang bagaimana resistensi pemimpin perempuan terhadap paham eks-HTI pada lembaga pendidikan Islam dasar di Kota Kediri.

Penelitian ini menggunakan pendekatan kualitatif berperspektif feminisme. Penelitian kualitatif merupakan usaha peneliti meahami fenomena yang diteliti melalui pengamatan perilaku atau tindakan-tindakan subjek yang disertai penggalian pemahaman kesadaran melalui persepsi atau cara pandang subjek penelitian (Rukin, 2019). Sedangkan pendekatan feminisme menjadikan peneliti memberikan ruang atau suara perempuan sebagai aktor atau sumber kunci utama (Muslikhati, 2004). Semua pendekatan tersebut dimanfaatkan secara holistik sebagai metode ilmiah.

Penelitian ini dilakukan pada lembaga pendidikan Islam dasar di Kota Kediri. Lembaga-lembaga pendidikan tersebut berafiliasai dengan organisasi keagamaan yang ada di Indonesia misalnya SDI AL Huda yang berafiliasi dengan NU, SDS Wahidiyah yang berafiliasi dengan Wahidiyah dan SD Plus Ar Rahmat yang berafiliasi dengan Muhamadiyah. Hanya ketiga lembaga ini menggambarkan kondisi lembaga pendidikan Islam dasar di Kota Kediri. Karena organisasi yang lain belum mempunyai pendidikan Islam dasar seperti Lembaga Dakwah Islam Indonesia (LDII) ataupun yang lain.

Informan kunci dalam penelitian ini adalah para kepala sekolah dari ketiga lembaga pendidikan dasar Islam tersebut. Ibu Munawaroh, Kepala Sekolah SDI AL Huda Kota Kediri, Ibu Khoirul MahmudahKepala SDS Wahidiyah dan Sri Wahyuni, Kepala Sekolah SD Plus Ar Rahmat Kota Kediri. Penelitian ini menggunakan teknik wawancara, observasi dan studi dokumen-dokumen lembaga dan karya tulis ilmiah yang sesui denga tema penelitian.

\section{PEMBAHASAN}

\section{Gerakan Eks-HTI di Kota Kediri}

Pengikut atau simpatisan HTI sangat banyak di Indonesia, tidak terkecuali di Kota Kediri, meskipun pemerintah menerbitkan PERPU No. 2 Tahun 2017 tentang Organisasi Kemasyarakatan untuk menghentikan izin oeprasional organisasinya. 
Terbukti, banyak penceramah dari HTI mendakwah tentang ideologi HTI dengan nuansa hate speech yang ditujukan untuk pemerintah Indonesia dan tetap menggaungkan penggantian ideologi Pancasila. Keberhasilan perkrutan anggota atau simpatisan tidak bisa dilepaskan dari strategi infiltrasi HTI di semua komponen bangsa Indonesia (Rizki, 2018).

Sejatinya, upaya infiltrasi gerakan HTI di lingkungan Kota Kediri dilakukan melalui tiga cara, yaitu infiltrasi melalui kegiatan-kegiatan di masjid, kegiatan institusi, dan kegiatan politis. Proses inflitrasi berbasis masjid dilakukan melalui pendekatan terhadap masjid untuk membuat mimbar-mimbar dakwah dan penyebaran bulletin. Intensitas kegiatan yang sangat tinggi terlihat di Masjid Agung Kota Kediri dan Masjid Baiturahman. Infiltrasi, juga terlihat jelas di masjid terbuka dan tidak berafiliasi dengan ormas tertentu, yaitu Masjid Al-Muttaqien, Ngronggo. Meski demikian, akan tetapi infiltrasi dengan level rendah muncul di masjid-masjid umum lainnya misalnya, Masjid Pesantren Jamsaren, Masjid Komplek Al-Hikmah Banjaran dan, dan Masjid Kampus di Universitas Nusantara (UNP) PGRI Kediri.

Untuk melihat efektifitas strategi infiltrasi HTI di masjid-masjid bisa dilihat dari aspek kontrol. Dari aspek kontrol pengurus terhadap dakwah masjid ditemukan bahwa di masjid-masjid yang memiliki afiliasi dengan HTI kontrol pengurus sangat kuat. Keputusan tentang khatib/penceramah serta materi khutbah dan pengajian ditentukan secara otoritatif oleh ustadz yang sekaligus pimpinan pesantren yang memayungi masing-masing masjid ini. Di sisi lain, masjid-masjid yang dikelola oleh aktivis NU dan Muhammadiyah menjalankan fungsi kontrol yang tidak seketat kedua masjid di atas.

Sementara masjid-masjid yang dikelola pemerintah (Kemenag) kontrol dilakukan dari jauh pada khatib dan isi khutbah jumat, sedangkan untuk ceramah dan kegiatan pengajian di luar itu lebih longgar sehingga berbagai anasir radikal bisa menggunakan masjid untuk ajang dakwah. Penting untuk dicatat, bahwa tanpa adanya peningkatan kontrol dikhawatirkan tercipta keadaan yang beresiko terhadap infiltrasi ideologi radikal HTI (Prasetio, 2019).

Strategi infiltrasi HTI juga pada lembaga pendidikan. Beberapa SMA di Kota Kediri terindikasi telah menjadi tempat subur bagi tumbuhnya ideologi-ideologi HTI, walaupun tidak mengarah kepada hal-hal yang menuju konsep tegaknya khilafah. Kebanyakan ide yang dikembangkan di SMA adalah seputar ajakan untuk langsung mengembalikan seluruh persoalan yang diahadapi kepada Al Qur'an dan Al Hadist. Infiltrasi ideologi ini disisipkan melalui kegiatan ekstrakurikuler siswa semacam ekstra kerohanian atau kelompok kajian Islam yang ada di sekolah (Salim et al., 2018).

Di beberapa pendidikan tinggi juga sering ditemukan adanya halaqahhalaqah yang secara implisit mengkaji tentang ide-ide HTI. Halaqah ini ada yang bersifat independen, ada pula yang merasuk ke dalam Unit Kegiatan Mahasiswa. 
Selain itu, keberadaan buletin-buletin yang berisikan ajaran serta ideologi HTI juga sering ditemukan di sekitar kampus-kampus di wilayah Kota Kediri. Penulis sendiri telah berhasil menemukan buletin-buletin tersebut terutama di masjid-masjid sekitar kampus, yang sering juga digunakan untuk berdiskusi para mahasiswa.

Infiltrasi paham HTI di lembaga pendidikan Islam dasar di Kediri banyak kanalnya. Meski demikian, tidak sampai membesar. Sehingga, sampai saat ini tidak banyak terdengar beritanya. Hasil penelitian A. Jauhar Fuad menunjukkan bahwa proses infiltrasi paham HTI melalui bahan ajar. Contohnya pada tema tentang pembahasan surat al Kafirun. Dalam penjelasannya, penulis menjelaskan bahwa orang kafir boleh dibunuh. Ironisnya, dalam mendefinisikan orang kafir tidak hanya orang non-muslim, akan tetapi orang Islam yang melakukan kegiatan-kegiatan bid'ah (kegiatan amalan yang tidak dikerjakan oleh Nabi Muhammmad SAW) (Fuad, 2017).

Hal ini juga muncul dalam soal ujian semester SD kelas V. Dalam lembar ujian tersebut ditemukan pertanyaan tentang ideologi Pancasila. Bentuk pertanyaannya adalah, Bunyi pancasila terdapat pada:. Pilihan jawabann yang disediakan adalah Al Qur an, al Hadist, Kitab-Kitab salaf dan Undang-Undang Dasar 1945. Pertanyaan ini mengiring pendapat anak untuk menjadikan Al Qur'an sebagai panduan hidup, bukan yang lain. Menghadapi situasi demikian, pihak sekolah membantah bahwa soal-soal ujian itu bukan diproduksi oleh sekolah, akan tetapi Kementerian Agama (Kemenag) Kota Kediri. Ironisnya, tanggapan kemenag Kediri menjelaskan bahwa itu bentuk kecolongan. Meski demikian, tidak ada upaya untuk merevisi pemahaman tersebut.

Selain itu, melalui rekruitmen tenaga pengajar baru. Kasus ini terjadi pada SD Al Huda Kota Kediri. Saat itu test rekruitmen tidak mencantumkan materi-materi tentang amaliyah-amaliyah dari pemahaman ideologi Islam moderat. Saat diterima, guru ini mengajarkan agama dan pemahaman kehidupan berbangsa bernegara sesuai dengan pemahamn HTI. Menurut Ibu Munawaroh, saat dikonfirmasi kepada yang bersangkutan, ia menyadari bahwa pemahaman itu diambil dari internet ataupun media sosial. Menaggapi situasi tersebut, pihak yayasan dan sekolah tidak mengeluarkan, akan tetapi melakukan pembinaan dengan mewajibkan guru yang bersangkutan mengikuti kegiatan-kegiatan keagamaan yang diadakan oleh Yayasan Al Huda (Munawaroh, April 12, 2020).

Infiltrasi lain, melalui kegiatan peringatan hari besar keagamaan. Dalam kejadian ini, pihak sekolah mengundang mubaligh atau penceramah yang berafiliasi dengan HTI. Hal ini tentu tidak disadari, karena penceramah terkenal mempunyai keahlian memberikan motivasi. Hal ini terkuak saat anggota Pimpinan Cabang gerakan Pemuda Ansor (PC GP Ansor) melihat youtubenya. Saat dikonfirmasi, pihak sekolah menyatakan ketidaktahuannya. Dan sejak saat itu, pihak sekolah tidak lagi mengundang penceramah tersebut. Ketidaktahuan guru atau pengajar 
terhadap gerakan HTI, sejatinya menjadikan strategi infiltrasi efektif dilaksanakan di pendidikan. Selain itu, HTI juga mengambil peran, mendekati tokoh-tokoh kunci atau orang-orang yang berpengaruh dalam lembaga pendidikan, misalnya ketua yayasan, anggota yayasan dan lain sebagainya.

\section{Persepsi Pemimpin Perempuan di Lembaga Pendidikan Islam Dasar Terhadap Eks-HTI}

Hingga saat ini, istilah 'redikalisme' dianggap problematis. Misalnya, apa yang membedakan antara radikalisme dengan terorisme. Bahkan istilah radikal di dunia filsafat memiliki makna positif karena menunjukkan cara berpikir yang mendalam hingga akarnya. Ada sebuah joke, seorang mahasiswa mengatakan bahwa di kelas ia diminta berpikir radikal, namun di luar kelas dia ditangkap polisi (Hamdi, 2013).

Ada beberapa pihak yang telah mencoba mendefinisikan terma 'radikalisme' dalam isu kekerasan agama. Radikalisme didefinisikan sebagai, "Suatu sikap yang mendambakan perubahan total dan bersifat revolusioner dengan menjungkirbalikkan nilai-nilai yang ada secara drastis lewat kekerasan dan aksi-aksi yang ekstrim." Ciri-ciri yang melekat ke kelompok radikal: intoleran (tidak mau menghargai pendapat dan keyakinan orang lain), fanatik (selalu merasa benar sendiri, menganggap orang lain salah), eksklusif (membedakan dengan umat Islam umumnya), dan revolusioner (cenderung menggunakan cara-cara kekerasan untuk mencapai tujuan) (Robingatun, 2017).

Ada satu hal yang perlu digarasbawahi ketika membicarakan radikalisme, yaitu kekerasan. Memang, kata radikal secara harfiah berarti berakar atau mendasar atau menyeluruh. Sebagai istilah netral, istilah radikal tidak hanya merujuk pada gerakan atau kelompok sosial-keagamaan tertentu. Istilah radikal pernah digunakan oleh Nakamura dalam melabeli NU secara positif. Menurut Nakamura, NU adalah tradisionalis-radikal, dalam arti bahwa secara keagamaan NU tetap sebuah ormas Islam tradisionalis, namun sikap dan tindakan politiknya terhadap negara tergolong radikal. Radikal di sini diartikan sebagai sikap kritis yang mendasar, yang dilawankan dengan oportunistik yang selama ini dianggap sebagai sikap dan tindakan politik NU (Rijal, 2017).

Terkait dengan merebaknya berbagai kekerasan agama dan meledaknya terorisme di mana-mana, istilah radikal mendapatkan makna tambahan. Ia tidak semata-mata diartikan sebagai sebuah sikap dan tuntutan akan perubahan yang mendasar dan menyeluruh, tapi juga disertai dengan tindakan kekerasan. Sikap radikal pada akhirnya dianggap, sekalipun tidak selalu, membawa kepada tindakan kekerasan. Ini misalnya bisa dilacak dalam penjelasan Juergensmeyer tentang kekerasan agama. Kekerasan bermotif agama sesungguhnya lahir dari sebuah perspektif hitam-putih atas dunia, di mana kelompok musuh dianggap sebagai pasukan setan yang harus diperangi atas nama Tuhan. Jadi, jika seseorang menginginkan aturan Tuhan tegak di muka bumi, tidak ada jalan lain kecuali 
merobohkan tatanan setan. Semua daya akan dikerahkan termasuk jika harus dengan kekerasan. Inilah perang semesta (cosmic war) antara kekuatan kebenaran (Tuhan) dan kejahatan (setan).

Istilah 'Islam radikal' yang dimaksudkan dalam penelitian ini adalah kelompok atau gerakan ke-Islaman yang berjuang melakukan reformasi atau perubahan atas tata kehidupan sosial-budaya-politik secara mendasar dan menyeluruh (termasuk menuntut berdirinya negara Islam, berlakunya sharî‘ah Islam sebagai hukum negara, dipatuhinya ajaran Islam dalam kehidupan bermasyarakat), dan mereka menyetujui kekerasan sebagai sarana untuk mencapai tujuannya, baik mereka melakukan kekerasan atau tidak.

Dalam kaitannya dengan penggunaan kekerasan, istilah 'radikal' bisa berarti sinonim dengan militan yang secara harfiah bermakna "using force or strong pressure to achieve one's aims" (menggunakan kekuatan atau tekanan untuk mencapai tujuan). Istilah 'militan' dalam pengertian ini juga digunakan Saeed ketika dia melabeli kelompok jihadis seperti Osamah bin Laden sebagai militant extremist (Arifin \& Riza, n.d.)

The International Republican Institute (IRI) membagi radikal menjadi dua: cognitive radical dan behavioural radical. Cognitive radical merujuk pada orang yang menyetujui kekerasan tapi tidak mengambil bagian dalam tindakan kekerasa. Sedangkan behavioral radical adalah mereka yang menyetujui tindakan kekerasan dan terlibat dalam atau melakukan aksi kekerasan atas atas ideologi radikal yang diyakininya.

Jadi, radikalisme adalah sikap atau keyakinan yang begitu tinggi terhadap satu faham atau nilai yang membuat seseorang atau kelompok menutup kemungkinan benar faham/nilai dari individu/kelompok lain. Keyakinan kebenaran nilai hanya pada kelompoknya sering disertai dengan bahwa yang lain salah sehingga layak diabaikan, dihilangkan atau dihukum. Bisa dikatakan bahwa radikalisme adalah tindakan intoleransi dalam bentuk ekstrem disertai dengan kecenderungan menggunakan kekerasan yang ditujukan kepada orang atau sekolompok yang berbeda faham.

Sementara, radikalisasi adalah proses seseorang secara bertahap semakin menerima penggunaan kekerasan untuk mencapai baik itu tujuan politik, ideologi atau relijius. Radikalisasi juga dipahami sebagai proses mengadopsi sistem keyakinan yang ekstrem. Hal ini menjadi perspektif peneliti melihat HTI menjadi bagian kelompok dalam kategori berpaham radikal.

Ulasan ini, menggambarkan betapa gagapnya orang mengidektifikasi dan mengkategorikan kelompok radikal di kalangan peneliti atau penulis. Hal ini juga ditemukan penulis pada saat melakukan penelitian terhadap pemimpin perempuan pada lembaga pendidikan Islam dasar di Kota Kediri. Hampir semua responden tidak mempunyai patokan dan referensi yang jelas tentang paham radikalisme. 
Hal ini juga terjadi dalam penelitian ini. Semua pemimpin perempuan pada lembaga pendidikan Islam dasar di Kota Kediri. Seperti yang disampaikan Kepala Sekolah SDI AL Huda bahwa radikalisme adalah orang yang berpaham kekerasan. Kegamaan itu juga terlihat pada pemberian contoh kelompok yang dianggap berpaham radikal. Ia tidak berani mencontohkan organisasi di Indonesia yang berpaham radikal. Radikalisme itu, paham keagamaan yang keras. Di Indonesia tidak ada. Yang saya tahu yang berpaham radikal adalah ISIS. Yang di Indonesia hanya pahammnya,,, kata Bu Munawaroh (Munawaroh, April 12, 2020).

Kegamangan lain, juga disampaikan oleh Sri Wahyuni, S.TP., S.Pd.SD kepala SD Plus Ar Rahmat Kota Kediri. Ia menolak bahwa radikalisme itu salah. Menurutnya, HTI memang radikal, karena ingin mengubah ideology Negara Indonesia, Pancasila. Akan tetapi sikap radikal sangat diperlukan dalam beragama. Karena dengan sikap radikal, menunjukkan tingkat atau kadar keimanan seseorang (S. Wahyuni, April 12, 2020).

Senada dengan Ibu Sri Wahyuni, pandangan Kepala Sekolah SDS Wahidiyah. Menurutnya, sikap radikalisme dalam beragama itu penting, karena itu menunjukkan keimanan seseorang. Bagi kiai atau mursid selalu berupaya menanamkan sikap fanatik pada agama Islam dan Wahidyah. Jika ini tidak dipupuk, maka tingkat keagamaan seseorang akan mudah turun atau menipis.

Meski demikian, pandangan semua kepala sekolah perempuan pada lembaga pendidikan Islam dasar di Kota Kediri bahwa HTI adalah bagian dari kelompok keagamaan Islam yang berpandangan radikal. HTI disamakan dengan Islamic State in Iraq and Syria (ISIS). Akan tetapi semua narasumber menolak bahwa di Kediri ada simpatisan ISIS. Menurut mereka yang terlihat di Kediri adalah para annggota dan simpatisan HTI.

\section{Penerapan Pendidikan Interreligius}

Seperti yang dijelaskan sebelumnya, dalam penelitian ini tidak ditemukan pemahaman radikalisme yang fixed, akan tetapi semua informan menyadari bahwa HTI maupun eks-HTI menjadi ancaman terhadap kerukunan. Pendidikan menjadi saranan yang harus dikembangkan untuk melakukan penolakan terhadap paham eks-HTI. Strategi yang dikembangkan adalah konsep pendidikan interreligius.

Konsep pendidikan interreligious bisa diterapkan dan dikembangkan dari pola piker Jean Piaget. Berdasarkan teori Piaget, penulis menangkap bahwa kepala sekolah perempuan harus mengfasilitasi peran guru mengarahkan dan memfasilitasi proses adaptasi terhadap kenyataan realitas bermasyarakat, barbangsa dan bernegara. Kepala sekolah harus memahami kebutuhan masyarakat terhadap lulusan yang dihasilkan sesuai dengan karakter masyarakat (Hardianto, 2017).

Konsep ini sangat disadari oleh kepala sekolah SD Al Huda Kota Kediri, SDS Wahidiyah Kota Kediri dan SD Plus Ar Rahmat Kota Kediri. Program yang dikembangkan adalah penguatan kesadaran kebangsaan dan pengakuan terhadap 
pemeluk agama lain. Hal ini dilakukan dengan kunjungan terhadap beberapa rumah ibadah agama lain dan melakukan santunan kepada fakir miskin. Tujuan pokoknya adalah menghilangkan sifat sifat egosentrismenya. Dalam teori perkembangan anak, pola pikir, kesadaran sangat dipengaruhi oleh lingkungan ekternal. Penanaman nilai-nilai religious akan masuk menjadi ingatan jangka panjang. Hal ini menjadi modal utama untuk menanamkan karakter pluralis dan multikulturalis sejak dini (Sihotang et al., 2016).

Cara berfikir inilah, menjadi landasan untuk membuat program penanaman anak didik menolak paham-paham radikal termasuk HTI. Langkah-langkah yang dilakukandapat di bagi menjadi 2, langkah formal dan non-formal. Langkahlangkah formal adalah sebagai berikut:

\section{Seleksi Buku Pelajaran}

Salah satu bentuk upaya yang dilakukan kepala sekolah permpuan pada sekolah dasar dalam mengantisipasi adanya sisipan paham radikalisme dalam buku pelajaran adalah menyeleksi buku-buku tersebut. Buku merupakan media pokok yang digunakan dalam proses pembelajaran. Oleh karena itu, harus benar-benar diperhatikan, khususnya konten-konten yang terdapat dalam buku pelajaran Pendidikan Agama Islam (PAI). H-sebulan sebelum tahun ajaran baru, kepala sekolah membentim penyeleksi buku-buku yang akan menjadi penduan dalam pembelajaran. Tugasnya adalah melakukan seleksi buku-buku yang akan digunakan dalam pembelajaran, seperti konten atau materi yang ada di dalam buku.

Sebelum buku pelajaran tersebut sampai kepada peserta didik, merupakan hal yang baik jika diseleksi terlebih dahulu. Selain agar terhindar dari paham radikalisme yang terdapat di dalam buku, juga sebagai sarana penyesuaian dengan silabus. Penyeleksian buku-buku pelajaran tersebut dilakukan oleh semua time penyeleksi atas pertimbangan dan pengawasan dari Kepala Sekolah dan Waka kurikulum. Penyeleksian tersebut didasarkan pada pendidikan yang rahmatan lil 'àlamin dan jauh dari unsur-unsur radikalisme.

\section{Modul Pribadi}

Dalam menjalankan pembelajaran di SDS Wahidiyah, SD Puls Ar Rahmat dan SDI AL Huda mengikuti kurikulum nasional. Akan tetapi, tidak terpaku pada kurikulum nasional saja, keduasekolah ini juga memiliki modul sendiri. Modul ini dibuat untuk menambah wawasan peserta didik dan sebagai penunjang dalam mencapai tujuan dan visi misi sekolah dan penyesuaian dengan ideologi paham keagamaan yayasan. Hal yang paling penting adalah dapat menghindarkan peserta didik dari paham radikalisme.

Modul yang dibuat diantaranya adalah al-Qur'ān Ḥadìs, taḥsin, dan kitabah. Awal pembuatan modul ini dimulai dari Al Qur an dan Ḥadist, karena Al Qur an dan Hadist merupakan dasar pedoman hidup bagi manusia. Oleh karena itu, peserta didik harus paham dasar-dasar dalam beragama sehingga tidak terpengaruh oleh 
paham radikalisme. Pengembangan modul pribadi ini terus berlanjut hingga sekarang, karena dirasa cukup memberikan perubahan yang signifikan, terutama dalam penyeleksian buku pelajaran. Selain ketiga modul tersebut, saat ini sedang menggarap modul Fiqih yang kemungkinan akan diterbitkan pada Tahun 2019.

\section{Buku Panduan PAI}

SDS Wahidiyah, SD Plus Ar Rahmat dan SDI AL Huda memunyai buku pegangan khusus bagi guru. "Semua guru pelajaran agama Islam atau guru kelas yang mengajarkan materi pelajaran agama Islam wajib menggunakan buku panduan dari sekolah. Jadi, mereka boleh mempunyai pemahaman tentang apapun, tapi kalau sudah di sekolah khususnya dalam pembelajaran dan pengajaran PAI ke anak-anak wajib menggunakan buku panduan. Adanya buku panduan khusus ini bertujuan agar guru tidak melenceng dari visi misi sekolah dan tujuan pendidikan nasional di mana pembelajaran yang dilakukan di dalam atau pun di luar kelas berorientasi pada pembentukan karakter Islami dan nasionalisme.

Di dalam buku panduan tersebut terdapat ikrar dan janji menjadi pelajar Islam yang intinya harus taat kepada Allah dan menjalankan tugasnya sebagai seorang pelajar. Adapun isinya mencakup pelajaran PAI, diantaranya yaitu fiqh mencakup Bab Thaharah dan tata cara shalat. Akidah akhlak mencakup do'a-do'a harian yang dapat dipraktikkan ke dalam kehidupan sehari-hari seperti do'a mau tidur, do'a naik kendaraan, dan lainnya. Dan alqur'an hadis yang mencakup hadis-hadis pilihan sesuai dengan modul pribadi yang telah dibahas sebelumnya.

Buku panduan tersebut juga terdapat daftar pustaka. Artinya, berbagai materi yang ada dalam buku panduan tersebut tidak secara asal atau ngawur, tetapi berdasarkan panduan buku-buku bahkan kitab yang sudah ada dan teruji keabsahannya. Contohnya: Mukhtasar ihya' Ulumuddin karya imam ghazali, Tafsir al-Misbah; Pesan, Kesan, dan Keserasian al-Qur'an, karya Quraish Shihab, dan lainnya.

\section{Kegiatan Nasionalisme}

Kegiatan yang juga diupayakan adalah melakukan kegiatan-kegiatan nasionalisme. Nasionalisme dapat diartikan sebagai kemampuan mencintai bangsa dan negaraNasionalisme menuntut adanya perwujudan nilai-nilai dasar yang berorientasi pada kepentingan bersama, dan menghindarkan kepentingan ribadi yang berusak tatanan kehidupan bersama (Tsamarah, 2016).

Nasionalisme sebenarnya mengandung unsur pendidikan agama, bahkan disadari atau tidak, agama didefinisikan sebagai salah satu simbol nasionalisme. Nasionalisme berdasar negara Pancasila yang didalamnya terdapat unsur-unsur agama. Hal ini tersirat dalam sila-sila yang dikandung Pancasila adalah ajaran dasar yang terdapat dalam Islam. Secara tidak langsung ideologi negara Indonesia sudah memunyai ciri-ciri keislaman (Suyanto, 2012). 
Jadi, berbagai bentuk penolakan kelompok radikalisme terhadap Indonesia dan mendorong untuk mendirikan negara Islam bukanlah hal yang benar. Karena pada hakikatnya, Pancasila, dasar negara Indonesia saat ini sudah mengandung unsurunsur keislaman. Maka, agar peserta didik tidak mengarah pada penolakan yang demikian, Kepala sekolah SDS Wahidiyah, Kepala SDI AL Huda, SD Plus Ar Rahmat tetap melaksanakan kegiatan nasionalisme yang diimbangi dengan kegiatan-kegiatan keislaman, karena keduanya saling berkesinambungan. Dalam mewujudkan kedamaian dan kesatuan bangsa dan negara, maka diperlukan sikap nasionalisme beragama.

Semua itu menggunakan langkah formal, artinya berdasarkan program yang disetujui oleh yayasan masing-masing. Sedangkan langkah-langkah non-formal yang dilakukan oleh kepala sekolah pada lembaga pendidikan Islam dasar di Kota Kediri adalah sebagai berikut:

1. Pertemuan anggota keluarga antar guru dan karyawan

2. Silaturrahmi antar wali santri/wali murid

3. Membuat Group WA antara guru dan wali murid

Langkah-langkah tersebut sabagi strategi membuka jalur komunikasi dan saling berkirim informasi tentang keagamaan. Langkah ini sangat efektif karena di topang juga dengan kemampuan bahasa kepala sekolah perempuan yang identik dengan bahasa ibu dan anak.

\section{PENUTUP}

Penyebaran paham eks-HTI di Kota Kediri juga masuk dalam lembaga pendidikan Islam dasar. Hal ini disadai oleh pemimpin perempuan pada lembaga pendidikan Islam. Berdasarkan hasil penelitian, langkah-langkah yang dilakukan oleh kepala sekolah perempuan pada lembaga pendidikan Islam dasar dengan pendekatan formal dan non-formal. Pendekatan formal diputuskan berdasarkan persetujuan yayasan. Dan pendekatan non formal adalah kegiatan pertemuan-pertemuan di luar sekolah, seperti pertemuan anggota keluarga antara guru dan karyawan dan membuat media komunikasi guru dan wali santri atau wali murid. 


\section{DAFTAR PUSTAKA}

Arifin, Z., \& Riza, S. (n.d.). Menangkal Radikalisme Agama di Sekolah | Al Qodiri: Jurnal Pendidikan, Sosial dan Keagamaan. Retrieved June 16, 2020, from http:/ / ejournal.kopertais4.or.id/tapalkuda/index.php/qodiri/article/view $/ 2891$

Bruinessen, M. van. (1994). NU tradisi relasi-relasi kuasa pencarian wacana baru.

Fathurrohman, A., \& Nurhadi, M. (2016). Perencanaan Pembelajaran Guru Sekolah Dasar Dalam Materi Pendidikan Agama Islam Di Kabupaten Pasuruan. AtTajdid: Jurnal Ilmu Tarbiyah, 5(2), 219-242.

Fuad, A. J. (2017). Rekonstruk Buku Ajar Pendidikan Agama Islam Bermuatan Paham Radikal di Sekolah. Proceedings of Annual Conference for Muslim Scholars, Seri 2, 663-672.

Hamdi, A. Z. (2013). RADICALIZING INDONESIAN MODERATE ISLAM FROM WITHIN: The NU-FPI Relationship in Bangkalan, Madura. JOURNAL OF INDONESIAN ISLAM, 7(1), 71-95-95. https:/ / doi.org/10.15642/JIIS.2013.7.1.71-95

Hardianto, P. D. (2017). PENTINGNYA PENDIDIKAN INTERRELIGIUSITAS DI SEKOLAH DASAR. Jurnal Teologi, 3(1), 13-24-24. https:// doi.org/10.24071/jt.v3i1.448

Institute, S. (n.d.). INDEKS KOTA TOLERAN TAHUN 2018. Setara Institute. Retrieved June 16, 2020, from https://setara-institute.org/indeks-kotatoleran-tahun-2018/

Khatib, A. (2018). Perempuan Pamekasan Madura dan Organisasi Radikal (Kajian Resiliensi Perempuan atas Aliran Hizbut Tahrir Indonesia [HTI] di Pamekasan Madura). Jurnal Pemikiran Dan Ilmu Keislaman, 2(1), 353-368.

Kisbiyanto, K., \& Setyoningsih, S. (2018). Strategic Values in Madrasa Development in Kudus: Management Study of Islamic Education Perspective in Nusantara. ADDIN, 12(2), 473-490. https:// doi.org/10.21043/addin.v12i2.4051

Lubis, E. S. D. D. (2018). Infliltrasi Pemikiran Dan Gerakan HTI Di Indonesia. Universitas Muhamadiyah Surakarta.

Lutvi. (n.d.). Heboh Aksi Murid TK Asuhan Kodim 0820 Probolinggo dalam Karnaval Kemerdekaan, Ini Videonya-Tribun Medan. Retrieved June 17, 2020, from https:/ / medan.tribunnews.com/2018/08/18/heboh-aksi-murid-tk-asuhankodim-0820-probolinggo-dalam-karnaval-kemerdekaan-ini-video

Ma'arifah, A. D. N. (2019). Upaya Guru Pendidikan Agama islam (PAI) Dalam Mengembangkan Nilai-Nilai Keagamaan Siswa di SMK PGRI 3 Tulungagung [IAIN Tulungagung]. http:/ / repo.iain-tulungagung.ac.id/ Munawaroh. (2020, April 12). Wawancara [Personal communication]. 
Muslikhati, S. (2004). Feminisme dan pemberdayaan perempuan dalam timbangan Islam. Gema Insani.

Prasetio, B. (2019). Pembubaran Hizbut Tahrir di Indonesia dalam Perspektif Sosial Politik. Analisis: Jurnal Studi Keislaman, 19(2), 251-264. https:/ / doi.org/10.24042/ajsk.v19i2.3371

Rijal, S. (2017). RADIKALISME KAUM MUDA ISLAM TERDIDIK DI MAKASSAR. Al-Qalam, 23(2), Article 2. https:/ / doi.org/10.31969/alq.v23i2.434

Rizki, M. F. (2018). Deradikalisasi Pengikut Hizbut Tahrir Indonesia Pasca Terbitnya Perppu No.2 Tahun 2017 Tentang Ormas. Jurnal Politikom Indonesiana, 3(1), 164. https://doi.org/10.35706/jpi.v3i1.1420

Robingatun, R. (2017). RADIKALISME ISLAM DAN ANCAMAN KEBANGSAAN. EMPIRISMA: JURNAL PEMIKIRAN DAN KEBUDAYAAN ISLAM, 26(1), Article 1. https:/ / doi.org/10.30762/ empirisma.v26i1.684

Rukin. (2019). Metodologi Penelitian Kualitiatif. https:// books.google.co.id/books?id Salim, N., Suryanto, S., \& Widodo, A. (2018). Pencegahan Paham Radikalisme dan Terorisme Melalui Pendidikan Multikulturalisme pada Siswa MAN Kediri I. Jurnal ABDINUS: Jurnal Pengabdian Nusantara, 2(1), 99-107. https:// doi.org/10.29407/ja.v2i1.11988

Sihotang, N., Yusuf, A. M., \& Daharnis, D. (2016). Pengaruh Layanan Bimbingan Kelompok terhadap Pencapaian Tugas Perkembangan Remaja Awal dalam Aspek Kemandirian Emosional (Studi Eksperimen di SMP Frater Padang). Konselor, 2(4), 186-192-192. https:/ / doi.org/10.24036/02013242898-0-00

Suyanto, S. (2012). Pendidikan Karakter untuk Anak Usia Dini. Jurnal Pendidikan Anak, 1(1), Article 1. https:/ / doi.org/10.21831/jpa.v1i1.2898

Tsamarah, S. A. (2016). PENDIDIKAN NILAI NASIONALISME DI SD NEGERI 2 WATES KULON PROGO. BASIC EDUCATION, 5(29), 2-773-2.780.

Wahid Institut. (2015). Laporan Pemantauan KBB Tahun 2015. http:/ / www.wahidinstitute.org/wi-id/laporan-dan-publikasi/laporantahunan-kebebasan-beragama-dan-berkeyakinan/322-laporan-pemantauankbb-tahun-2015.html

Wahyuni, S. (2020, April 12). Wawancara [Personal communication].

Yani, A., \& Jazariyah, J. (2020). Penyelenggaraan PAUD Berbasis Karakter Kebhinekaan sebagai Upaya Pencegahan Radikalisme Sejak Dini. Jurnal Obsesi: Jurnal Pendidikan Anak Usia Dini, 5(1), 1-13. https:// doi.org/10.31004/obsesi.v5i1.503 